Amasya Ilahiyat Dergisi - Amasya Theology Journal

ISSN 2667-7326 | e-ISSN 2667-6710

Haziran / June 2020, 14: 51-79

\title{
Endülüs Müslümanlarının II. Bayezid'e Yazdığı İstiğâse (Feryadname) Kasidesi
}

\section{The Qasīdah (Faryādnāma) Written to Bāyezid II by Andalusian Muslims}

\author{
Ramazan MEŞE \\ Dr. Öğr. Üyesi, İnönü Üniversitesi, İlahiyat Fakültesi, \\ Arap Dili ve Belağatı Anabilim Dalı \\ Assistant Professor, İnonu University, Faculty of Theology, \\ Department of Arabic Language and al-Balagha \\ Malatya, Turkey \\ ramazan.mese@inonu.edu.tr \\ orcid.org/0000-0001-8524-7923
}

\section{Makale Bilgisi / Article Information}

Makale Türü / Article Types: Araştırma Makalesi / Research Article Geliş Tarihi / Received: 12 Mart / March 2020

Kabul Tarihi / Accepted: 27 Nisan / April 2020

Yayın Tarihi / Published: 30 Haziran / June 2020

Yayın Sezonu / Pub. Date Season: Haziran / June

Sayı / Issue: 14 Sayfa / Pages: 51-79

Atıf / Cite as: Meşe, Ramazan. “Endülüs Müslümanlarının II. Bayezid'e Yazdığı İstiğâse (Feryadname) Kasidesi [The Qasīdah (Faryādnāma) Written to Bāyezid II by Andalusian Muslims]". Amasya Illahiyat Dergisi-Amasya Theology Journal 14 (June 2020): 51-79.

https://doi.org/10.18498/amailad. 702964.

Intihal / Plagiarism: Bu makale, en az iki hakem tarafından incelendi ve intihal içermediği teyit edildi. / This article has been reviewed by at least two referees and scanned via a plagiarism software.

Copyright (C) Published by Amasya Üniversitesi, İlahiyat Fakültesi / Amasya University, Faculty of Theology, Amasya, 05100 Turkey. All rights reserved. https://dergipark.org.tr/amailad. 
52 | R. MEŞE / Endülüs Müslümanlarının II. Bayezid'e Yazdığı İstiğâse (Feryadname) Kasidesi

\title{
The Qasīdah (Faryādnāma) Written to Bāyezid II by Andalusian Muslims
}

\begin{abstract}
The civilization built by Muslims through eight centuries on Iberian Peninsula ended up by the collapse of the last Andalusian Islamic polity, Banu al-Ahmar in 898/1492. After this collapse, remaining Muslim population on the peninsula who were insulted by the new rulers called help from the powerful Muslim rulers from around the world. They conveyed this message of help via screaming (faryādnāma) poems to those Muslim leaders with messengers. In these qasidas they pictured the oppression and the difficulty they faced. One of these qasidas which are historical records, reached to the Ottoman sultan Bāyezid II and they asked help from him as well. Andalusians wrote two qasidas. One of these was written before the collapse of Banu al-Ahmar (12381492) in order to inform the Sultan about the Christians' attacks. The other was written because of the assimilation policy undertaken against Muslims after 1492. In this study, this latter qasīdah istighāsah will be examined. In introduction, history of Andalusia, Banu al-Ahmar's collapse and the oppression faced by the remaining Muslims will be touched upon briefly. Then, the definition of qasīdah istighāsah will be given and the subject qasīdah will be studied with its Turkish translation given.
\end{abstract}

\section{Summary}

The Islamic domination that lasted for nearly eight centuries in Andalusia ended with the collapse of the last Andalusian Islamic State, Banu al-Ahmar, in 898/1492. After the fall of Banu al-Ahmar State, Christians tried to completely destroy the existence of Muslims in the peninsula. As a matter of fact, they followed a harsh and brutal attitude towards Muslims in order to reach their goals. With this policy of assimilation, they forced Muslims to change their religion, and prevented them from speaking their language, and intervened in their daily lives. They punished those who did not comply with the prohibitions they placed. In particular, they judged those who insisted on not changing their religion in the Inquisition courts. After this collapse, remaining Muslim population on the peninsula who were insulted by the new rulers called help from the powerful Muslim rulers from around the world. They conveyed this message of help via istighāsah (faryādnāma) poems. In these qasidas they pictured the oppression and the difficulty they faced. One of these qasidas which are historical records, reached to the Ottoman sultan Bāyezid II and they asked help from him as well. The Muslims of Andalusia sent a qasīdah 
istighāsah, composed of 105 couplets, to him in 906/1501 and asked him to come to the rescue of the Andalusian Muslims.

As a theme of poetry istighāsah is the request of the poet from his interlocutor for help due to the difficult situation he or his society is in. Although this theme is examined also under the title of marsiyya (elegiac poetry), when they are examined it is seen that they differ from the marsiyya for cities in terms of its content and structure. Therefore, they should be examined as two separate themes.

Andalusian Muslims wrote two qasīdah istighāsah to Bāyezid II. The first of these is the written because Christians occupied the state from all sides before the Banu al-Ahmar State collapsed. It is written by Abu'l-Bakâ al-Rundî and is evaluated under the theme of marsiyya as well. The second is written in 906/1501, which reveals the oppression and persecution of Muslims after their domination in Andalusia in 898/1492 ended completely. This one is a historical document. The expressions of the oppression and persecution faced by the Muslims in this last letter reveal difficult the severity of the events in that period. The knowledge of these letters written to Bayyezid II, on the one hand, provides us with the oppression and persecution faced by the Muslims at that time, on the other hand, the foundation of the political events of that period.

Banu al-Ahmar's collapse and the oppression faced by the remaining Muslims will be touched upon briefly. Then, the definition of qasīdah istighāsah will be given and the subject qasīdah will be studied with its Turkish translation given. Whether it is in our country or in the Arab world, there is no study that deals with the aforementioned qasīdah in detail and examines it under the subject of istighāsah. However, Azmi Yüksel the qasīdah has been translated under the title of “From Endülüs'ten II. Bayezid'a Yazılan Anonim Bir Şiir"and published in Belleten Journal in 1988. In addition, M. Faruk Toprak examined the subject of istighāsah as a separate theme of poetry in his article, "Endülüs Şiirinde İstiğâse", published in Ankara Üniversitesi Dil ve Tarih-Coğrafya Fakültesi Dergisi. In his study, Toprak examined some of the couplets by partially mentioning the aforementioned qasīdah. Shihâbuddîn al-Makkarî gives the full text of this qasīdah in his book "Azhâru'r-riyâd fi ahbâri al-Qâdî 'iyâd". Apart from this, its full text can also be found in "al-Dawlatu'l-'Uthmâniyya-avâmil al-nuhîd wa asbâb al-sukût-" by Ali Muhammad Muhammead al-Sallâbî. It is also partially mentioned in some other sources dealing with the themes of istighāsah and marsiyya for cities, and in some historical sources that informing about the existence of such a qasīdah. 


\section{4 | R. MEŞE / Endülüs Müslümanlarının II. Bayezid'e Yazdığı İstiğâse (Feryadname) Kasidesi}

The absence of a detailed study about this qasidah has made it necessary to consider and evaluate it. This qasidah, which is examined under the theme of istighāsah in Arabic poetry, presents the political events of the period in which it was written, but also gives information about the content and structure of the istighāsah poems. Therefore, this study, on the one hand, aims to complete the missing information about the political history of the period basing on such a historical document; on the other hand, it aims to provide information about the content of the content and structure of the istighāsah poems.

In introduction, first, history of Andalusia, Banu al-Ahmar's collapse and the oppression faced by the remaining Muslims will be touched upon briefly to prepare the ground for work. The biggest reason for the writing of the aforementioned qasidah was that after the collapse of the Muslim state, the Muslims were subjected to persecutions as a result of being defenseless. Second, the poem of istighāsah will be evaluated as a theme of poetry. Third, after the etymological meaning of the word istighāsah is given, the poems written under the theme of istighāsah are being mentioned. In particular, some information is given about the theme of this poetry in Andalusia and the poets who wrote the poetry of under this theme. Fourth, I will provide an introductory information about the qasīdah composed of 105 couplets written to Bāyezid II. After all these, all couplets of the qasīdah will be translated into Turkish and evaluated. Information obtained from historical sources is also given about the events and situations that Muslims described in the qasīdah under evaluation.

It will be concluded that after the collapse of the last Andalusian Islamic state, Benu al-Ahmar, the Muslims who remained there asked for help from the Ottoman Empire and that they reported this request with an qasiddah istighāsah. It is observed that Muslims describe the difficult situation in which they lived in all details. Therefore, the attitude towards Muslims in Andalusia is observed with all its clarity at that time through this qasidah istighāsah. In addition, the content and structure of the such poems written in that period will be revealed.

Keywords: Arabic Language and Literature, Andalusia, Istighāsah, Bāyezid II, Qasīdah.

\section{Endülüs Müslümanlarının II. Bayezid'e Yazdığı İstiğâse (Feryadname) Kasidesi}

Öz

İber yarımadasında yaklaşık sekiz asır boyunca Müslümanların oluşturmuş olduğu görkemli medeniyet, son Endülüs İslam Devleti Benî Ahmer'in 898/1492' de yıkılması ile son bulmuştur. Benî Ahmer Devleti'nin yıkılmasından 
sonra yarımadada kalan Müslümanlara karşı takınılan sert ve acımasız tavır karşısında yarımadadaki Müslümanlar, dönemin güçlü Müslüman devlet başkanlarından yardım istemişlerdir. $\mathrm{Bu}$ yardım taleplerini de istiğâse (feryadname) kasideleri yazarak elçi vasıtasıyla bu devlet başkanlarına iletmişlerdir. Bu kasidelerde içinde bulundukları zor durumu dile getirip maruz kaldıkları baskı ve zulmü tasvir etmişlerdir. Tarihi bir belge niteliğinde olan bu kasideler Osmanlı Devleti padişahlarından II. Bayezid'e da ulaşmış ve ondan yardım talep edilmiştir. Endülüslüler II. Bayezid'e iki istiğâse kasidesi yazmıştır. Bunların birincisi henüz Benî Ahmer Devleti (1238-1492) yıkılmadan önce Hıristiyanların dört bir taraftan devleti işgal etmelerinden dolayı yazılan istiğâse kasidedir. İkincisi ise Benî Ahmer Devleti'nin yıkılmasından sonra Müslümanların maruz kaldığı asimilasyon politikasından dolayı yazılan istiğâse kasidesidir. Bu çalışmada Endülüs'te son Müslüman devleti olan Benî Ahmer Devleti düştükten sonra Endülüs Müslümanların Osmanlı Padişahı II. Bayezid'e yazdıkları istiğâse kasidesi değerlendirilecektir. Tarihi bir vesika olan bu kasideye geçmeden önce girişte Endülüs tarihinden, son Endülüs Müslüman Devleti Benî Ahmer'in yıkılışı ve bundan sonra Endülüs'te kalan Müslümanların yaşadıkları Hıristiyan baskılarından kısaca bahsedilecektir. Daha sonra istiğâse şiiri tarif edilerek söz konusu kaside tercümesi yapılarak değerlendirilecektir.

Anahtar Kelimeler: Arap Dili ve Edebiyatı, Endülüs, İstiğâse, II. Bayezid, Kaside.

\section{Giriş}

Müslümanların 898/1492 yılında Endülüs'te hâkimiyetleri tamamen son bulduktan sonra gördükleri baskı ve zulümleri tüm çıplaklığıyla ortaya koyan, 906/1501'de II. Bayezid'e yazılan istiğâse (feryadname) kasidesi, tarihi bir vesika niteliğindedir. Bu kasideye geçmeden önce son Endülüs devleti olan Benî Ahmer ve bu devletin yıkılmasından sonra gelişen olaylar ile bu süreçte Müslümanların bölgede yaşadıkları ve bu kasideyi yazmalarına sebep olan olaylardan haberdar olmak kasidenin anlaşılmasına katkı sağlayacaktır.

Târık b. Ziyâd tarafından 102/720 yılında fethedilen Endülüs'te Müslümanların siyasî varlığı, 898/1492 yılına kadar yaklaşık sekiz asır sürmüştür. Endülüs'ün fethiyle başlayıp Benî Ahmer Devleti ile son 
bulan Müslüman hâkimiyeti, belli bir döneme kadar ilerleme kaydetmiş daha sonrasinda ise gerileyerek son bulmuştur. ${ }^{1}$

Endülüs'te hüküm süren son Müslüman devlet olan Benî Ahmer, Muvahhidler'in yıkılmasından sonra İbnü'l-Ahmer diye bilinen Muhammed b. Yûsuf tarafından 635/1238 tarihinde kurulmuştur. ${ }^{2} 250$ yıldan fazla hükümden Benî Ahmer Devleti, kurucusu İbnü'l-Ahmer'e nispetle "Benî Ahmer", başkentine nispetle "Grrnata Sultanlığı" veya "Gırnata Emirliği" olarak da isimlendirilir. ${ }^{3} \mathrm{Bu}$ Müslüman devleti Hıristiyanlara karşı uzun süre mücadele etmiş ancak zamanla küçülmek zorunda kalmış ve elinde kalan son şehir olan Gırnata'yı da 898/1492 teslim etmiştir. Bu son hanedanın yıkılmasıyla da Endülüs'te Müslüman hâkimiyeti son bulmuştur. ${ }^{4}$

898/1492'de Girnata'nın anahtarları Hıristiyanlara teslim edildikten sonra Müslüman halkın bir kısmı Mağrib'e göç etmiştir. ${ }^{5}$ Endülüs Müslümanlarının büyük bir çoğunluğu Hıristiyan idarecilerin kendilerine verdikleri söze inandıklarından Endülüs'ten çıkmadılar. ${ }^{6}$ Ancak bu sözlerinden 903/1497 yılından itibaren dönmeye başladılar. İlk medeni haklarda kısıtlamalar bu tarihte başladı. Güvenlik maksadıyla silah taşımaları yasaklandı ve idari meclislerdeki görevleri ellerinden alındı. Merkezde oturanlar şehrin kenar mahallerine taşınmaya zorlandı. Diğer bölgelerde yaşayan Hıristiyanlar ise Müslümanların boşalttıkları evlere yerleştirildiler. 905/1499 yılından itibaren ise şehirde yaşayan Müslümanlar zorla Hıristiyanlaştırılmaya çalışıldı. Ancak çoğu Endülüslü dinini değiştirmiş gibi yaparak Müslümanlığına devam etti. $\mathrm{Bu}$ şekilde olanlara da "Morisko" denildi.7 İlk zamanlar bir takım vaatlerle Müslümanlar Hıristiyanlaştırmaya çalışılmış ancak bunun

1 Geniş bilgi için bk. Mehmet Özdemir, “Endülüs”, Türkiye Diyanet Vakfı İslam Ansiklopedisi (İstanbul: TDV Yayınları, 1995), 11/211-213.

2 İsmail Yiğit, "Nasriler", Türkiye Diyanet Vakfi İslam Ansiklopedisi (İstanbul: TDV Yayınlar1, 2006), 32/420.

3 Yiğit, “Nasriler”, 32/420.

4 Geniş bilgi için bk. Özdemir, "Endülüs”, 11/216.

5 Özdemir, "Girnata", Türkiye Diyanet Vakfi İslam Ansiklopedisi (İstanbul: TDV Yayınları, 1996), 14/54.

6 Endülüs'te kalıp oradan çıkmayanlara "Müdeccen” denir. Bk. Özdemir, "Müdeccenler", Türkiye Diyanet Vakfi İslam Ansiklopedisi (İstanbul: TDV Yayınları, 2006), 31/465-467.

7 Morisko hakkında bilgi için bk. Özdemir, "Morisko", Türkiye Diyanet Vakfı İslam Ansiklopedisi (İstanbul: TDV Yayınları, 2005), 30/288-291. 
fayda vermeyeceğini anlayınca İslam ile ilgili bilgi kaynakları ve Arapça bilgi kaynaklarının okunması yasaklanmış ayrıca bu kaynaklar toplatılıp yakılmıştır. Moriskoların Arapça konuşması yasaklanmış, örf ve adetlerini yaşamalarına müsaade edilmemiştir. Hıristiyan olmayan Müslümanlara işkenceler edilmiş ve bazıları diri diri yakılmıştır. Camiler kiliseye çevrilmiş ve ibadet etmek yasaklanmıştır. En nihayetinde 907/1502 yılında Hıristiyan olmayanlardan ülkeyi terk etmeleri istenmiştir. Ayrıca zorla Hıristiyanlaştırılan ancak kalbinde İslam'ı yaşayan Müslümanların yeni dinlerine bağlılıklarını ölçmek gayesiyle engizisyon mahkemeleri kurulmuş ve bu mahkemeler neticesinde Moriskolara işkenceler yapılmıştır. ${ }^{8}$

Batı'da bunlar yaşanırken Endülüslüler bir kurtuluş yolu aramışlardır. Bu sebeple Endülüs'te Müslüman hâkimiyeti son bulmadan önce diğer Müslüman devlet yöneticilerine yardım etmeleri için elçiler göndermişler, bu elçilerle beraber istiğâse kasideleri iletmişlerdir. Son Müslüman devleti olan Benî Ahmer düştükten sonra da Endülüslüler gerek Osmanlı padişahlarına gerekse o dönemin büyük devletlerinden Memluklülere elçiler göndermiş ve Hiristiyanların baskılarından kurtulmak için yardım istemişlerdir.

Endülüslerin Osmanlı'dan yardım istemeleri henüz Benî Ahmer Devleti düşmeden önce 892/1487 yılında ilk olarak olmuştur. İkinci kez yardım istemeleri ise 906/1501 yılında gerçekleşmiştir. Her iki yardım talebinde de Endülüs'ten gönderilen elçi padişahın huzurunda etkili bir istiğâse şiiri okumuştur. İşte bu çalışmada ikinci kez Endülüslülerin yazıp II. Bayezid'e gönderdikleri elçinin okuduğu 105 beyitten oluşan kaside incelenecektir. Ayrıca bu kaside Azmi Yüksel tarafından “Endülüs'ten II. Bayezid'a Anonim Bir Şiir" başlığı altında incelenmiş ve çevirisi yapılmıştır. ${ }^{9}$ Bu çalışmada yazar dönemin tarihinden kısaca bahsetmiş, kaside hakkında bilgi verdikten sonra kasidenin metnini vermeden tercümesini yapmıştır. Ayrıca dipnotlarda da beyitlerin bir kısmının tarihi arka planına değinmiştir. Bu çalışmada ise söz konusu

8 Gırnata düştükten sonra Müslümanların maruz kaldıkları baskı ve zulüm hakkında bk. Feridun Bilgin, “Gırnata İşgali Sonrasında Endülüs'teki Müslümanların Asimilasyonu", Mukaddime Dergisi 2 (2010), 53-78.

9 Bk. Azmi Yüksel, “Endülüs'ten II. Bayezid'a Anonim Bir Şiir”, Belleten 3/205 (Aralık 1988), 1576-1583. 
kasidenin tanıtılmasına katkı sağlaması gayesi ile öncelikle istiğâse şiiri tanitılarak; kaside daha detaylı bir şekilde ele alınmaya çalışılmıştır.

Osmanlı Devletinin Endülüs'e yardım edip etmediği veya etmedi ise neden yardım etmediği tarihçiler tarafından tartışılmıştır. Ancak genel olarak birkaç kez yardım talebinde bulunan Endülüslülerin bekledikleri yardımı kısmen elde ettikleri tarih kaynaklarında geçmektedir. ${ }^{10}$

\section{1. İstiğâse Şiiri}

Arapçada (غيث) yağmur, (غوث) ise yardım dileme, imdat çağrısı ile alakalı olarak kullanılır. İstiğâse ise (غوث) kelimesi ile alakalı olup, "g-v$\mathrm{s}^{\prime \prime}$ ecvef fiilinin istif'âl babından mastarıdır. Sözlükte yardım isteme, imdat çağrısında bulunma gibi anlamlara gelir. ${ }^{11}$ Kelime olarak elistisrâh (الاستصراخ), el-istincâd (الاستنجاد), el-isticâr (الإستجار), el-isticâş̧ (الإستجاش) gibi kelimelerle eş anlamlıdır. ${ }^{12}$ Terim anlamı ise güç ve kuvvet sahibi birine yardım ve kurtuluş için çağrıda bulunmaya denir.

İstiğâse kelimesi Kur'an'da sıkıntı ve zorluktan kurtulmak için Yüce Allah'tan talepte bulunmak anlamında kullanılmıştır. ${ }^{13}$ Mesela

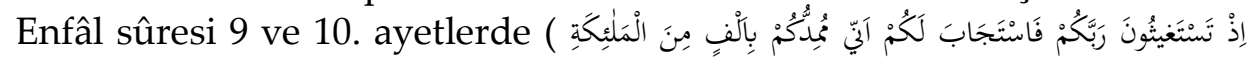
(مرْرِفينَ) "Hani Rabbinizden yardım istiyordunuz da, O, 'Ben size peş peşe bin melekle yardım ediyorum' diye cevap vermişti" yardım dileme, yalvarma anlamında kullanılmıştır. Bunun dışındaki ayetlerde de genel olarak zor ve sıkıntılı durumdan kurtulmak için yardım talep etme, sığınma, gibi anlamlarda kullanıldığ 1 söylenebilir. ${ }^{14}$

10 Bk. İsmail Hakkı Uzunçarşıll, Osmanlı Tarihi (Ankara: Türk Dil Kurumu Basımevi, 1988), 2/192-200; Özdemir, "Osmanlı Endülüs Müslümanlarına Yardım Etmedi mi?”, İslâmî Araştırmalar Dergisi 12/3-4 (1999), 283-296.

11 Halîl b. Ahmed el-Ferâhîdî, "ğvs", Kitâbu'l- 'ayn, thk. Mehdî el-Mahzûmî - İbrâhîm es-Samerrâî (Lübnan: Dâru ve Mektebetü'l-Hilâl, ts.), 4/440; Ebû Bekr Muhammed İbn Dureyd el-Ezdî, "s s̆v", Cemheretü'l-lüğa, thk. Remzî Munîr Ba lebekî (Beyrut: Dâru'l-'İlm li'l-Melâyîn, 1407/1987), 1/429; Muhammed b. 'Abdurrezzâk el-Hüseynî Ebü'l-Feyd ez-Zebîdî, "ğvs", Tâcu'l-arûs min cevâhiri'l-kâmûs, thk. 'Alî Hilâlî (Kuveyt: Matba 'âtü Hukûmeti'l-Kuveyt, 1427/2003), 5/313.

12 Ebû Abdillâh Cemâlüddîn Muhammed b. Abdillâh b. Mâlik et-Tâî el-Endelüsî elCeyyânî, el-Elfâzu'l-muhtelifetü fíl-meâni'l-mu'telife, thk. Muhammed Hasan Avâd (Beyrut: Dâru'l-Cîl, 1411/1990), 179.

13 Abdurrahman Kasapoğlu, “Kur'an'da Dini Bir Tecrübe Olarak Allah'tan Yardım Dileme ve O'na Muhtaçlık "İstiâne", "İstiğâse" ve "Fakr İla'llâh", İnönü Üniversitesi İlahiyat Fakültesi Dergisi 5/2 (Güz 2014), 113.

14 İlgili ayetler için bk. Kehf 18/29; Kasas 28/15; Ahkâf 46/15. 
Bir şiir teması olarak istiğâse, şairin kendisinin ya da yaşadığı toplumun içinde bulunduğu zor durumdan dolayı muhatabindan yardım talep etmesi, ondan destek istemesi olarak karşımıza çıkar.

Endülüs Devleti zayıflamaya ve elindeki şehirleri kaybetmeye başlayınca burada yaşayan Müslümanlar, Hıristiyanlar tarafından baskı ve zulme maruz bırakılmışlardır. Müslümanların Hıristiyanlar karşısında zor zamanlar yaşaması edebiyata da yansımış ve özellikle şiir alanında iki temanın gelişmesine zemin hazırlamıştır. Bunlardan birincisi kaybedilen şehirlere yazılan mersiye teması olurken ikincisi ise diğer ülkedeki Müslümanları yardıma çağıran istiğâse teması olmuştur. Her ne kadar bu iki şiir teması şehirlere mersiye başlı̆̆ı altında ele alınmışsa da bu iki temada yazılan şiirlerin gerek içerik olarak gerekse de yazılış amaçları farklı olduğu söylenebilir. Şehirlere mersiye genellikle kaybedilen veya tahrip edilen şehirler için söylenirken, istiğâse şiiri henüz kaybedilmemiş bir şehrin kurtuluşu ya da bu şehirde yaşayan insanları içinde bulundukları zor durumdan kurtuluş için söylenen şiirlerdir. İstiğâse şiirinde şehirlere yazılan mersiye gibi karamsarlık ve umutsuzluk hâkim değildir. Bilakis bu şiirlerde Müslümanlar yaşadığı zorluk ve sıkıntılara rağmen bir umut vardır. Dolayısıyla bu beyitlerde diğger ülke Müslümanlarını yardıma çağırma, onları cihada teşvik konuları işlenir. Bunun güzel örneklerinden biri Endülüs şehirlerinden Belensiye'nin kuşatma altına alındığında İbnü'1Abbâr'ın (ö. 658/1260) yazmış olduğu ve Tunus'ta Hafsîler Devletinin Sultanı olan Ebû Zekeriyya b. Ebî Hafs'ın (ö. 647/1249) huzurunda okuduğu şiirdir. ${ }^{15}$ İbnü'l-Abbâr etkileyici bir çağrı ile başlayarak şöyle demiştir: 16
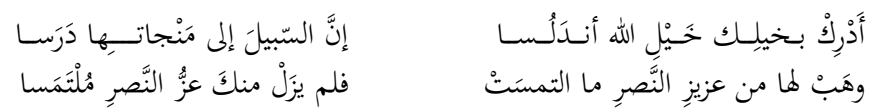

“Endülüs'ün imdadına Allah'ın ordusu olan atlarınla yetiş. Onun kurtuluşuna uzanan yollar silindi.

15 Tahir Ahmed Mekkî, Dirâsât Endülüsiyye fíll-edeb ve't-târîh ve'l-felsefe (Kahire: Dâru Me ârif, 1407/1987), 266.

16 Ebû 'Abdullah Muhammed b. 'Abdulmelik el-Ensârî el-Merrâküşî, ez-Zeyl ve'ttekmile lî kitâbi'l-mevsûl ve's-sila, thk. İhsân 'Abbâs vd. (Tunus: Dâru'l-Ğarbi'l-İslâmî, 1433/2012), 4/283; Şihâbuddîn Ahmed b. Muhammed el-Tilimsânî el-Makkarî, Ezhâru'r-riyâd fi ehbâri el-Kâdî 'Iyâd, thk. Mustafa es-Sekkâ vd. (Kahire: Matba'âtu Lecneti't-Te'lîf, 1357/1939), 3/207; Muhammed Abdullah Anân, Devletü'l-İslâm fi'lEndelüs (Kahire: Mektebetü'l-Hanicî, 1417/1997), 4/446. 
60 | R. MEŞE / Endülüs Müslümanlarının II. Bayezid'e Yazdığı İstiğâse (Feryadname) Kasidesi

Senden istediği değerli yardımı ona bağışla. Değerli yardımın senden hâlâ istenmektedir."

Bu kısa girişten sonra Endülüs topraklarında yaşananları anlatan şair duygularını şöyle ifade etmiştir:17

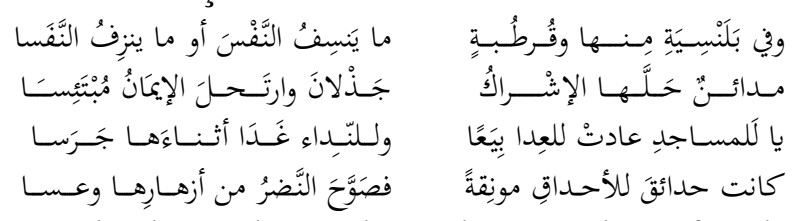

"Belensiye ve Kurtuba'da canlar söküp alan ya da nefesi kesenler olmuştur.

Şirk meydanlara sevinçle girerken, iman da umutsuz bir şekilde ayrulmıştır.

Vah camilere ki düşmanların kilisesi haline gelmiş, vah ezana ki de okunma vaktinde çan sesine dönmüştür.

Bahçelerin parlaklığı gözleri kamaştırırken şimdi o bahçenin çiçekleri soldu ve karardr."

Anlaşılan o ki İbnü'l-Abbâr Müslümanların Endülüs topraklarında yaşadıklarını burada veciz ifadelerle aktarmaya çalışmıştır. Burada birkaç beytini verdiğimiz ancak kasidenin büyük bir kısmında Belensiye'deki Müslümanların yaşadıkları zor durum üzerinde durulmuş ve bu durum tasvir edilmeye çalışılmıştır. Bu durum ilk üç beyit hariç 24 . beyte kadar devam etmiştir. ${ }^{18}$

Sonraki beyitlerde şair yardım talep ettiği Hafsîler Devleti yöneticisi Ebû Zekeriyyâ b. Ebî Hafs'1 methetmeye geçmiştir. İstiğâse şiirlerinin olmazsa olmazlarından olan medih kısmında şair, Ebû Hafs'1 uzun uzun övmüştür. Bu övgü beyitlerinden birkaç tanesinde şöyle demiştir: ${ }^{19}$
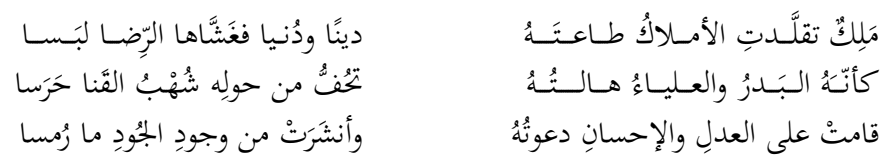

17 Merrâküşî, ez-Zeyl ve't-tekmile, 4/283; el-Makkarî, Ezhâru'r-riyâd, 3/207-208; 'Anân, Devletü'l-İslâm fi'l-Endelüs, 4/446-447.

18 Bk. Abdulbâkî Hüseyn Abdulbâkî Muhammed, "Sînîyyetü İbnü'l-Abbâr -dirâse belâğiyye nakdiyye-“, Mecelletü Külliyeti'l-Lügati'l-Arabiyye bi Asyût 30/4 (Aralık 2011), 2293-2341.

19 Merrâküşî, ez-Zeyl ve't-tekmile, 4/284; Makkarî, Ezhâru'r-riyâd, 3/209; 'Anân, Devletü'lİslâm fi'l-Endelüs, 4/447. 
R. MEŞE / The Qasīdah (Faryādnāma) Written to Bāyezid II by Andalusian Muslims | 61

"Öyle bir kral ki krallar din ve dünya işlerinde onun itaatine girer. O da onlara rıza elbisesini giydirmiştir.

$O$ adete dolunaydır. Yücelik de onun ışık halkasıdır, çevresinde onu koruyan parlak mızrak başlı̆̆ gibidir.

Onun çă̆rısı ile adalet ve ihsan ayă̆a kalktı ve toprağa gömülen cömertlik yeniden dirildi."

İbnü'1-Abbâr 60. beyte kadar İbn Hafs'1 övdükten sonra tekrardan Endülüs topraklarındaki Müslümanlar için yardım talebinde bulunmaya başlamıştır. Önce Endülüs topraklarında olanları tek tek anlatarak yardım çağrısında bulunması ve sonra da yardım talebinde bulunduğu kişiyi birçok özelliği ile övmesi yardım çağrısına zemin hazırlamak içindir. Ayrıca şairin içinde bulundukları durumu anlatıp onu övmesi muhatabının kalbini ve dikkatini çekmek için kullandığı bir yöntemdir. Bütün bu hazırlıklardan sonra da şu beyitlerle Hafsîler Devleti Sultan'indan yardım talebinde bulunmuştur:20
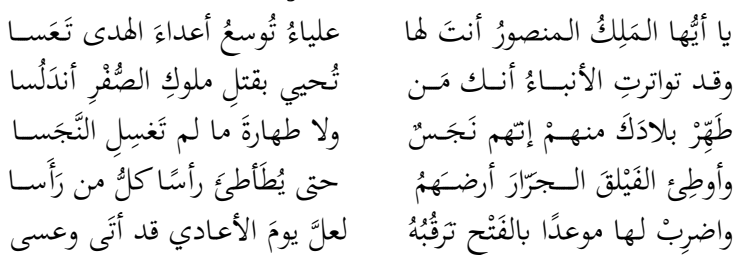

“Ey İslam düşmanlarının yüceliğ i ile karamsarliğa düştüğü muzaffer kral!

Senin Endülüs'ü Rum krallarını öldürerek tekrardan canlandıracă̆ın haberi peş peşe geldi.

Ülkeni (yani Endülüs'ü) onlardan temizle. Zira onlar pistirler. Pisliğgi temizlemeyenin temizliği olmaz.

Büyük ordunla onların toprakların çiğne ki orada baş olanları başını eğsinler.

Oranın (Endülüs) fethini gözettiğin bir gün belirle. Ola ki düşman bir an önce çıkıp gelir."

$\mathrm{Bu}$ son beyitlerle beraber şair şiirine son vermiştir. Assl meramı ve derdi olan meseleyi en sona birakarak muhatabın zihninde talep edilen şeyin kalıcılığını sağlamaya çalışmıştır.

67 beyitten oluşan bu şiirde İbnü'l-Abbâr girişte kısa bir yardım talebinde bulunup daha sonra Belensiye kuşatmasından dolayı Müslümanların yaşadıkları zor zamanları ve genel olarak Müslümanlara

20 Merrâküşî, ez-Zeyl ve't-tekmile, 4/286; Makkarî, Ezhâru'r-riyâd, 3/210. 
Rumlar tarafından reva görülen muameleleri detaylı bir şekilde anlatmıştır. Bu kısımdan sonra yardım talep ettiği Hafsîler Devleti Sultanı Ebû Zekeriyya'yı övmeye başlamış ve kasidenin yaklaşık 36 beytini bu kısma ayırmıştır. Son beyitlerde de etkileyici olduğu anlaşılan beyitlerle istiğâsede bulunmuştur.

İbnü'l-Abbâr'ın bu muazzam şiiri ve bu şiirin tahlili hakkında konuşmak sayfalar alabilir. Zira bu şiirin her kelimesine derin anlamlar yüklenmiştir. Nitekim bu kasideyi ele alarak edebî ve belâğî yönden derinlemesine inceleyen Ezher Üniversitesi öğretim üyelerinden Abdulbâkî Hüseyn, 150 sayfalık çalışmasını "Sînîyyetü İbnü'l-Abbâr Dirâse Belâğiyye ve Nakdiyye-" adıyla 2011 senesinde Asyût Arap Dili Fakültesi İlmi Dergisi'nde yayınlamıştır. ${ }^{21}$

Edebiyat tarihinin kaydettiği en meşhur istiğâse kasidelerinden biri olan bu kaside, istiğâse şiirinin üslup ve içeriği hakkında bizlere bilgi verir. Ayrıca bu kasidede işlenen konular genel olarak istiğâse şiirlerinde işlenen konular hakkında da bize bir fikir sunmaktadır. Nitekim bu kasidede şair ağırlıklı olarak içinde bulunulan durumu tasvir, yaşanan zor ve sıkıntılı sürece ağlama, yardım talep edilen kişiyi övme ve yardım talebinde bulunma gibi konuları işlemiştir.

İstiğâse şiiri ve bu şiir teması hakkında yukarıda verdiğimiz örnekle yetinip ${ }^{22}$ asıl konumuz olan II. Bayezid'e yazılan istiğâse şiiri üzerinde duracağız.

\section{II. Bayezid'e Yazılan İstiğâse (Feryadname) Kasidesi}

Osmanl1-Endülüs ilişkilerinin II. Bayezid (ö. 918/1512) döneminde başladığına dair kaynaklar hemfikirdir. ${ }^{23}$ Kastilya Krallığ İ̀spanya' daki son Müslüman devletinin hâkimiyetine son vermek için harekete geçip 887/1482' de Hame, 890/1485'te Runde, 892/1487' de ise Mâlaka işgal edince Endülüs'teki son Müslüman Devleti Benî Ahmer tehlike ile karşı karşıya geldi. Bunun üzerine o dönem Benî Ahmer Devleti'nin başında bulunan Ebû Abdillâh es-Sağîr (XII. Muhammed), Ebu'l-Bekâ erRundî'nin (ö. 684/1285) yazdığı kasideyi bir elçi vasıtası ile II. Bayezid'e göndermiştir. ${ }^{24}$ Kâtip Çelebi'nin (ö. 1067/1657) “Kasidetü Garra” olarak

${ }^{21}$ Bk. Abdulbâkî Muhammed, "Sînîyyetü İbnü'l-Abbâr -dirâse belâğiyye nakdiyye-“, 2286-2436.

22 Buna benzer bir diğer istiğâse şiirini ise Lisânüddin İbnü'l-Hatîb (ö. 776/1374-75) Mağrip halkına yazmıştır. Bk. 'Anân, Devletü'l-İslâm fi'l-Endelüs, 5/190.

23 Bk. Özdemir, “Osmanlı Endülüs Müslümanlarına Yardım Etmedi mi?”, 285.

24 Uzunçarşıll, Osmanlı Tarihi, 2/195. 
R. MEŞE / The Qasīdah (Faryādnāma) Written to Bāyezid II by Andalusian Muslims | 63 isimlendirdiği kaside, Endülüs'ün büyük bir bölümünün Müslümanların elinden çıkıp Hıristiyanların eline geçmesinden dolayı yazılan bir mersiyedir. Kasidenin ilk 12 beytinde her şeyin sonunun olduğunu, dünyanın geçiciliğinden bahsedilmiştir. Daha sonra 27. beyte kadar olan kısımda Endülüs Müslümanların içinde bulunduğu durum tasvir edilmiştir. Geri kalan beyitlerde de bir yandan cihada teşvik edilirken bir yandan da Endülüs'ün imdadına yetişilmesi için yardım talebinde bulunulmuş ve Endülüs Müslümanlarının yaşadıkları trajedi aktarılmıştır. ${ }^{25}$

$\mathrm{Bu}$ dönemde Osmanlı Devleti, deniz kuvvetlerinin yeteri güce sahip olamaması ve Avrupa'da Cem Sultan ile uğraşmasından dolayı istenilen yardımı yapamamıştır. Ancak daha sonra 911/1505'de İspanya sahillerine Kemal Reis kumandasında bir filo gönderilmiş ve bir kısım Müslüman ve Yahudi kurtarılarak Osmanlı topraklarına getirilmiştir. ${ }^{26}$ Aynı maksatla XII. Muhammed, Kuzey Afrika'daki Müslüman hanedanlara ve Memluk Devleti'ne de elçi göndermiş ve onlardan da yardım istemiştir. ${ }^{27}$

Yardım talepleri yeterince karşılık bulamayınca Benî Ahmer Devleti, Hıristiyanlar ile Ocak 1492 (27 Safer 897) senesinde Endülüs'teki hâkimiyetlerine son verecek 56 maddeden oluşan bir anlaşma imzalamıştır. ${ }^{28}$ Anlaşmaya göre Müslümanlara eziyet edilmeyecek, onlara din ve vicdan özgürlüğü tanınacaktı. ${ }^{29}$ Ancak bu anlaşmaya uyulmamış ve bundan sonra gün geçtikçe Müslümanlara uygulanan eziyet artarak devam etmiştir..$^{30}$ Buna karşılık Müslümanlar ayaklanmış iseler de bu ayaklanmaları kanlı bir şekilde bastırılmıştır. İsyana katılanlar vaftiz edilmeye zorlanmış, vaftizi kabul etmeyenler ise sürgün edilmiştir. ${ }^{31}$

Hristiyanların anlaşmayı bozmasından sonra Endülüs Müslümanları 906/1501 senesinde ikinci bir kez Osmanlı Devleti'nden

25 Kaside için bk. Makkarî, Ezhâru'r-riyâd fi ehbâri el-Kâdî 'İyâd, 1/48.

26 Uzunçarşılı, Osmanlı Tarihi, 2/195.

27 Halîl İbrâhîm es-Sâmerrâî vd., Târîhü'l-Arab ve Hadaratuhum fîl-Endelüs (Beyrut: Dâru'1-Kitâbi'l-Cedîdi'l-Muttehide, 1420/2000), 309.

28 'Anân, Devletü'l-íslâm fi'l-Endelüs, 5/244.

29 Bu anlaşmanın maddeleri için bk. 'Anân, Devletü'l-İslâm fi'l-Endelüs, 5/245-250.

30 Uzunçarşıll, Osmalı Tarihi, 2/195.

31 Özdemir, “Osmanlı Endülüs Müslümanlarına Yardım Etmedi mi?”, 287. 
64 | R. MEŞE / Endülüs Müslümanlarının II. Bayezid'e Yazdığı İstiğâse (Feryadname) Kasidesi yardım talebinde bulunmuşlardır. ${ }^{32}$ Endülüslerin ikinci kez II. Bayezid'e istiğâse kasidesi gönderip yardım talep etmeleri Benî Ahmer Devleti'nin yıkılmasından sonra gerçekleşmiştir. ${ }^{33}$ Edip ve biyografi yazarı elMakkarî'nin (ö. 1041/1632) "Ezhâru'l-Riyâd" isimli eserinde karşılaştığımız bu kaside 105 beyitten oluşmaktadır. ${ }^{34}$ Bu beyitlerin kim tarafından kaleme alındığı bilinmemektedir. Ancak Endülüs Gırnata halkından II. Bayezid'a geldiği tarih kaynaklarında sabittir. ${ }^{35}$ Bir tarihi vesika önemi taşıyan bu kaside aslında bir feryadnamenin yanında aynı zamanda o dönemde İspanya'da Müslümanların neler yaşadığını da ortaya koymaktadır. O zamanlar Hiristiyanların merkezi olan İspanya'da engizisyon mahkemelerince Müslümanlara reva görülenleri tüm çıplaklığıyla gözler önüne sermektedir.

Bu ikinci kaside neticesinde ünlü denizci Kemal Reis, 1505 yılında donanma ile Akdeniz'e gönderilmiştir. Kemal Reis ve ona bağlı birlikler Mâlaka ve Balear adalarını vurmuşlar ve birçok Moriskoyu Kuzey Afrika'ya getirmişlerdir. Sonraki süreçte Osmanlı tarafından yardımlar Barbaros Hayrettin Paşa komutasında birlikler vasıtasıyla gerçekleşip Endülüs'te yaşayan birçok Morisko İspanyolların zulmünden kurtarılmıştır. ${ }^{36}$

Gırnata düştükten sonra yazılan tâiyye kasidesinin dili gayet yalın ve açıktır. Şair muhatabının kolay anlayabileceği kelimeleri tercih etmiş ve karmaşık ifadelerden kaçınmıştır. Şimdi bu kasideyi pasajlar halinde ele alıp çevirisi ile birlikte değerlendireceğiz.

Kasidenin ilk 18 beytinde şair II. Bayezid'i selamlamaktadır. Bu 18 beyitlik kismin ilk sekiz beytinde selam ile beraber II. Bayezid övülmüştür. Bu beyitler şöyledir:
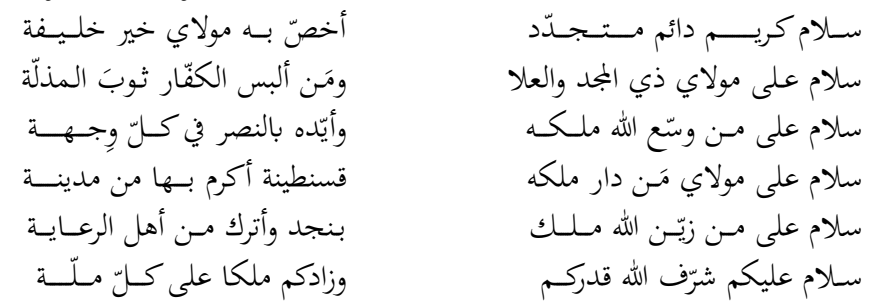

32 Özdemir, “Osmanlı Endülüs Müslümanlarına Yardım Etmedi mi?”, 286.

33 Sâmerrâî vd., Târîhü'l-Arab ve Hadaratuhum fì'l-Endelüs, 309.

34 Kaside için bk. Makkarî, Ezhâru'r-riyâd, 1/109-115.

35 Uzunçarşıll, Osmanlı Tarihi, 2/195.

36 Özdemir, “Osmanlı Endülüs Müslümanlarına Yardım Etmedi mi?”, 287. 
R. MEŞE / The Qasīdah (Faryādnāma) Written to Bāyezid II by Andalusian Muslims | 65

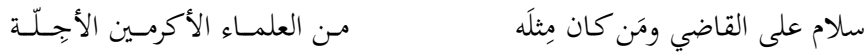

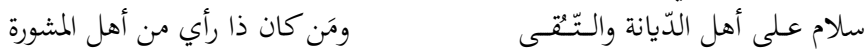

1. Sürekli yenilenen kutsal selamim en hayırl halife efendimedir.

2. Selam kâfirlere zillet elbisesini giydiren şeref sahibi, yüce efendime olsun.

3. Selam Allah'ın saltanatını genişlettiği ve her yerde zaferle güçlendirdiği kimseye olsun.

4. Selam saltanatının yeri İstanbul olan efendime olsun. O şehir ne kadar da güzeldir!

5. Selam Allah'ın saltanatını ordular ile donattığı ve halkı Türklerden olan kişiye olsun.

6. Selam Allah'ın kadrinizi yücelttiğgi ve hükümranlı̆̆ın bütün milletlerden üstün tuttuğu sizlere olsun.

7. Selam kadı ve ona benzeyen ulu ve yüce âlimlere olsun.

8. Selam din ve takva sahiplerine ve görüşsahibi danışmanlara olsun.

$\mathrm{Bu}$ ilk 8 beyitte şair asıl konuya girmeden önce II. Bayezid'i selamlamakta ve aynı zamanda övmektedir. Sadece II. Bayezid'i değil onun kadılarını, din adamlarını, âlimlerini ve danışmanlarını da selamlamaktadır. Kaside girizgâhına selam ve medihle ile başlayarak asıl meramını ifade etmeye zemin hazırlamaktadır. Nitekim asıl konuya geçiş yaparken de bir müddet selamlama kısmını devam ettirmektedir. Ancak burada selamladığı kişiyi övmeyi bırakarak içinde bulundukları durumu tasvir ederek selamlamaya devam etmektedir:

$$
\begin{aligned}
& \text { بأندلس بالغرب في أرض غُـــــــة }
\end{aligned}
$$

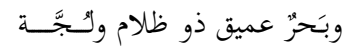

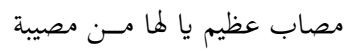

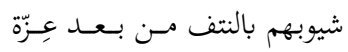

$$
\begin{aligned}
& \text { على جملة الأعلاج من بعد سترة }
\end{aligned}
$$

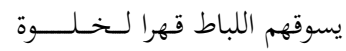

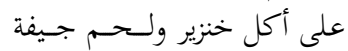

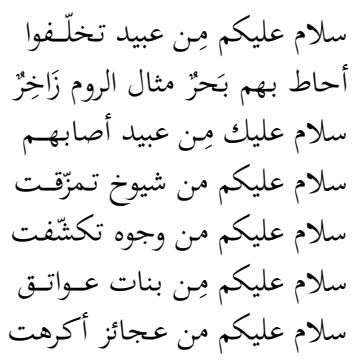

9. Endülüs'te vatanindan uzak topraklarda Batı'da kalan kölelerden sizlere selam olsun.

10. Rumlar gibi karanlık, engin, taşkm ve derin bir deniz onları çevrelemiştir.

11. Büyük bir musibete uğramış kölelerden sizlere selam olsun. Ne büyük bir musibettir o!

12. Şerefli bir hayattan sonra saçındaki beyazlar yolunarak pare pare olan yaşlilardan sizlere selam olsun. 
66 | R. MEŞE / Endülüs Müslümanlarının II. Bayezid'e Yazdığı İstiğâse (Feryadname) Kasidesi

13. Daha önce kapalı iken kafirler önünde açılan yüzlerden sizlere selam olsun.

14. Keşişlerin zorla halvete götürdüğ̈̈ hür kızlardan sizlere selam olsun.

15. Domuz ve leş eti yenmeye zorlanan yaşlılardan sizlere selam olsun.

Görüldüğü gibi şair bu pasajda bir yandan selamlama kısmını sürdürürken bir yandan da içinde bulundukları durumu tasvir etmektedir. Vatanından uzak topraklar derken de asıl vatanının Doğu olduğuna işaret etmektedir. Nitekim Endülüs Müslümanları her zaman Doğu'ya bir özlem duymuşlar ve bu konuda da birçok şiir nazmetmişlerdir. ${ }^{37}$ Daha sonra şair Rumların karanlık deniz gibi üzerlerine geldiğini ve başlarına büyük bir musibet geldiğini ifade ettikten sonra tesettür, domuz eti yememe, iffet gibi dini değerlerinin hiçe sayıldığını söylemiştir. Aslında şair bu beyitlerde selamlama kısmını uzun tutup asıl talebine zemin hazırlamak istemiştir. Ancak başlarına gelen felaketin büyüklüğüne sabredemeyerek selamlama yaparken dahi Rumların yapmış oldukları bu zulmü ifade etmeye çalışmıştır. Bu da içinde bulundukları durumun ne kadar vahim olduğunun bir göstergesidir. Selamlama kısmı bittikten sonra üç beyitle de II. Bayezid'e dua etmektedir:

$$
\begin{aligned}
& \text { نُقبّل نحن الكل أرض بساطلم وندعو لكم بالخير كلّ ساعة }
\end{aligned}
$$

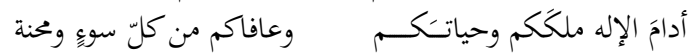

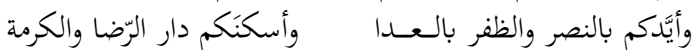

16. Hepimiz bastı̆̆ınız yeri öper ve her an iyiliğiniz için dua ederiz.

17. Allah saltanatınızı ve hayatınızı devam ettirsin ve sizleri her türlü kötülük ve beladan korusun.

18. Düşmana karşı sizleri zafer ve nusret ile güçlendirsin ve sizi razı olduğu güzel bir yerde iskân ettirsin.

$\mathrm{Bu}$ dua beyitlerinden sonra içinde bulundukları durumu tasvir etmeye başlayan şair ilk olarak Hristiyanlar ile aralarında geçen mücadeleyi 30. beyte kadar anlatıyor:

$$
\begin{aligned}
& \text { من الضّرّ والبلوى وعظم الرزيّة }
\end{aligned}
$$

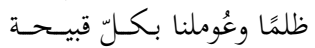

$$
\begin{aligned}
& \text { نقاتل عمّال الصّـليب بِـــــيّة }
\end{aligned}
$$

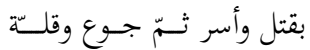

$$
\begin{aligned}
& \text { بسيل عظيم جملة بعد جـملة }
\end{aligned}
$$

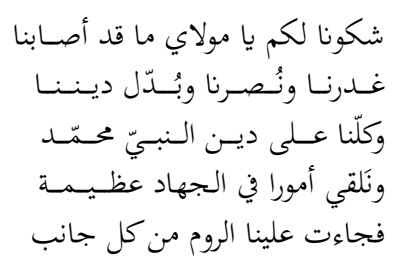

37 Bk. Selahattin Goran, Endülüs Arap Şiirinde Vatan Özlemi (Ankara: Ankara Üniversitesi, Sosyal Bilimler Enstitüsü, Doktora Tezi, 2003). 
R. MEŞE / The Qasīdah (Faryādnāma) Written to Bāyezid II by Andalusian Muslims | 67

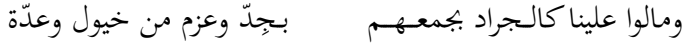

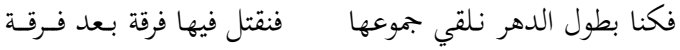

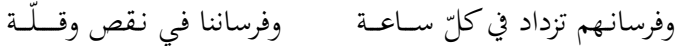

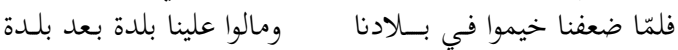

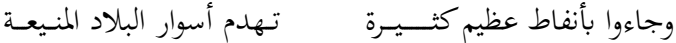

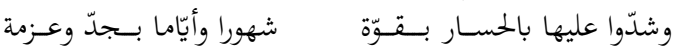

19. Ey efendim! Başımıza gelen bu zarar, musibet ve büyük felaketten dolayı size şikâyette bulunmuştuk.

20. Aldatıldık, Hıristiyanlaştırıldık ve zorla dinimiz değgiştirildi ve kötü muameleye maruz kaldık.

21. Hepimiz Peygamber Muhammed'in (s.a.v) dini üzerinde iken haçlı çocukları ile içtenlikle savaştık.

22. Cihat ederken büyük zorluklarla karşılaştık. Ölüm, esaret ve sonra açlık kıtlık...

23. Rumlar her taraftan üzerimize büyük bir sel gibi akın akın saldirdilar.

24. Birçok atlar ile azim ve ciddiyetleri ile topyekûn çekirge sürüsü gibi bizi ezdiler.

25. Buna rağmen biz kahramanca onlara karşı koyduk ve onlardan grup grup öldürdük.

26. Onların süvarileri her vakitte çoğalırken bizim süvarilerimiz azalmaktaydr.

27. Zayıfladığımızda ise ülkemize yerleştiler ve peş peşe şehirlerimizde egemen oldular.

28. Birçok büyük toplarıyla ülkenin sağlam surlarını yıktılar.

29. Günlerce, aylarca azim ve kararlllikla güçlü bir şekilde ülkemizi kuşatmalarını sürdürdüler.

Bu pasajda ilk olarak başına gelenlerden dolayı şikâyetlerini dile getirmişlerdir. Adeta bir mektup yazar gibi Rumlarla kendileri arasında gelişen süreci tek tek anlatmıştır. 20. beyitteki "aldatıldık" ifadesi, daha önce de bahsi geçen ve Rumlarla aralarında imzalanan anlaşmaya işarettir. Rumların bu anlaşmaya uymadıklarını, onlar tarafından din değiştirmeye zorlandıklarını ve kötü muameleye maruz kaldıklarını ifade etmiştir. Daha sonra ise Rumlarla mücadele ettiklerini ancak zamanla zayıfladıklarını ve onlara karşı duramadıkları söylemiştir. En nihayetinde işgale maruz kaldıklarını da ifade etmiştir.

Daha sonra da bu mücadeleyi verirken kimseden herhangi bir yardım görmediklerini söyleyerek bu mücadeleyi kaybedince az önce 
edilmiş ancak Osmanlı Devleti'nin o dönem içinde bulunduğu şartlar gereği yardım edilememişti. İşte şair işgal devam ederken herhangi bir yardım gelmediğinden ve kendileri de mücadele edecek gücü kaybettiklerinde söz konusu anlaşmayı imzalamak zorunda kaldıklarını ifade etmiştir. Bu anlaşmanın maddelerinden kısaca bahseden şair aslında var olan bu maddelere uyulmadığının da mesajını vermektedir. Ayrıca anlaşma maddelerinin 55'ten fazla olduğunu ifade etmektedir. Yine şair yukarıdaki pasajda anlaşmaya boyun eğmek zorunda kalmalarının sebeplerini saymaktadır. Öyle anlaşılıyor ki bir toplumda din ve vicdan özgürlüğü, vatan, ırz ve namus gibi değerlerin yokluğu o toplumu istemedikleri birtakım şeyleri kabul etmeye zorlamaktadır.

Bundan sonra da 64 . beyte kadar onların bu anlaşmayı bozduklarını ve Hıristiyanların orada Müslümanlara yaptıkları muameleyi etkili bir şekilde tek tek aktarmaya çalışmıştır. Orada yaşanan acı tabloyu gözler önüne sererek haline ağlayan şair, şöyle şiire devam etmektedir:
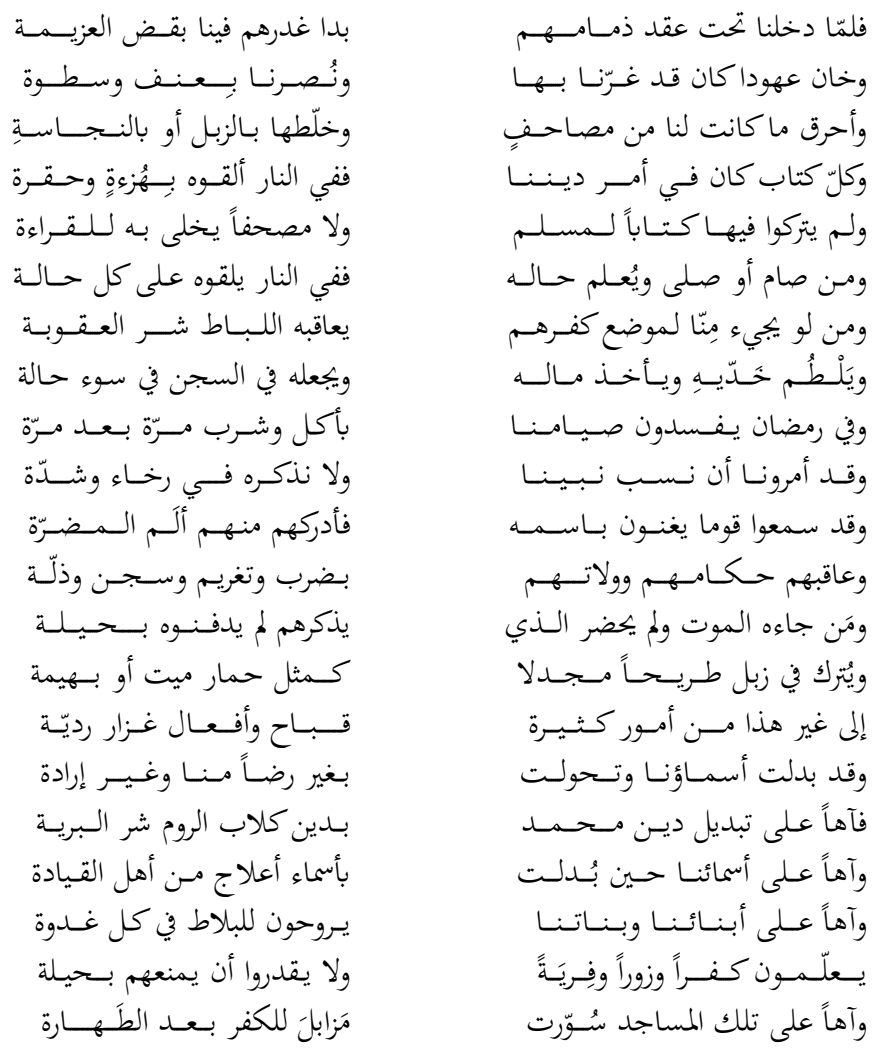
70 | R. MEŞE / Endülüs Müslümanlarının II. Bayezid'e Yazdığı İstiğâse (Feryadname) Kasidesi
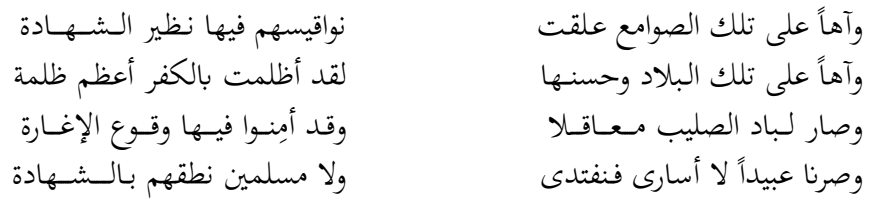

40. Onların teminatları altına girdiğimizde anlaşmayı bozarak bize ihanet ettikleri ortaya çıktı.

41. Bizi kendisi ile aldattığı anlaşmalara kendisi uymadı. Zorla ve şiddet kullanarak bizi Hiristiyanlaştırdr.

42. Elimizdeki bütün Mushafları yaktı ve onları pislik ve çöplüğe attı.

43. Din hakkında yazılmış kitaplarımızı alay ve aşă̆ılama ile ateşe attı.

44. Müslüman için orada ne bir kitap ne de yalnız kaldığında okuyacă̆ bir Mushaf biraktılar.

45. Her kim oruç tutar ya da namaz kular ve bu hali bilinirse her hâlükârda ateşe atılırdı.

46. Bizden her kim küfür mekânlarnna (kiliselerine) gitmezse papazlar tarafindan feci bir şekilde cezalandırılırdı.

47. (O papazlar) tokatlıyordu, malını alıyordu ve onu kötü bir durumda hapse atıyordu.

48. Ramazan ayında sürekli yiyip içerek oruçlarımızı ifsat ediyorlardı.

49. Peygamberimize sövmeyi bize emrettiler. İyi ve kötü günde onu anamiyoruz.

50. Bir grubu onun ismini anarken duydular ve o gruba elim bir şekilde eziyet ettiler.

51. Hâkimleri ve valileri onları döverek, para cezası vererek, hapsederek ve eziyet ederek cezalandirdi.

52. Biri öldü̈̆̈̈̈nde ve onlarm dinini telkin edecek biri gelmediğinde hile ile ölen kimseyi defnetmiyorlard.

53. Ölmüş bir eşek ya da bir hayvan gibi yere serilmiş şekilde çöplüğe terkediliyordu.

54. Bunun dışında birçok çirkin işler ve aşă̆̆llık eylemler vardı.

55. İsimlerimiz bizim rızamız ve irademiz dışında değiştirildi.

56. Muhammed'in dininin yerine mahlûkatın en aşă̆ılı̆̆g olan Rum köpeklerinin dininin konulması ne acı!

57. Kaba ve Arap olmayanların isimleri ile isimlerimizin değişmesi ne kadar da acı!

58. Her sabah papaza giden oğullarımız ve kızlarımızın durumu ne kadar da kötü! 
R. MEŞE / The Qasīdah (Faryādnāma) Written to Bāyezid II by Andalusian Muslims | 71

59. Onlara küfrü, batılı ve yalanı öğrettikleri halde onların (Müslümanlı̆̆ına) hile ile mani olamadılar.

60. Temiz ve pak olmalarından sonra küfre çöplük olması için duvarlarla çevrilen mescitlere ne kadar da yazı!!

61. Şehadete (ezana) bedel olarak çanlarının asildığı minarelere ne kadar da yazık!

62. Küfürle kapkara olmuş şu şehirlere ve güzelliklerine ne kadar da yazık!

63. Haça tapanlara kale haline geldiler. Saldırı olduğunda kendileri orada emniyete alyor.

64. Köleleştik, ne fidye vereceğimiz esirler olduk ne de şehadet getiren Müslümanlar.

Yukarıdaki pasajda ilk olarak şair yapılan anlaşmaya değinmiş ve bu anlaşmanin bozulduğuna işaret etmiştir. Nitekim Müslüman ve Yahudiler yapılan bu anlaşma ilk olarak Yahudiler karşı bozulmuş daha sonra da müdeccen olarak yaşayan Müslümanlara karşı bozulmuştur. Anlaşma bozulduktan sonra Müslümanlara karşı koyu Katolik olan kilisenin etkisi altındaki Rum yöneticilerin Müslümanlara karşı takındıkları tavırları bir bir anlatmıştır. İlk olarak zorla dinlerinin değiştirildiğinden bahsetmiştir. Bilindiği üzere zorla dinleri değiştirilen ancak içinde hala İslam'ı yaşayanlara Morisko denilirdi. Moriskoların evlerinde Kur'an bulundurmaları, Arapça eser bulundurmaları, namaz kılmaları, oruç tutmaları vb. yasaktı. Bunun dışında yukarıdaki pasajda anlatılan baskıcı ve zorlayıcı uygulamaların hepsi Moriskolara reva görülmüş ve onların asimile olmaları için her türlü kötü muamele yapılmıştır. Bütün bunlara şair ağlamakta ve bu durumların ne kadar acı bir şey olduğunu ifade etmektedir.

64. pasaja kadar olan bu acı tabloyu sunan şair, aslında durumun ne kadar vahim olduğunu ve bir an önce müdahale edilmezse Endülüs'te Müslüman kalmayacağına işaret etmiştir. Nitekim öyle de oldu. Endülüs'teki Müslüman varlığ1 tamamen yok edildi. Orada kerhen kalan Müslümanlar da kimlikleri gizlemek zorunda kalarak orada tutunmaya çalıştılar. ${ }^{38}$

38 Bk. Lütfi Şeyban, "Hıristiyan İşgalinde Endülüs Şehirleri", Eski Yeni: 3 Aylık Düşünce Dergisi 1 (Bahar 2006), 29. 
72 | R. MEŞE / Endülüs Müslümanlarının II. Bayezid'e Yazdığı İstiğâse (Feryadname) Kasidesi

Şair içinde bulundukları durumu anlattıktan sonra şikâyetlerini doğrudan II. Bayezid'e yönelterek 76 . beyte yardım talebinde bulunmaktadir:
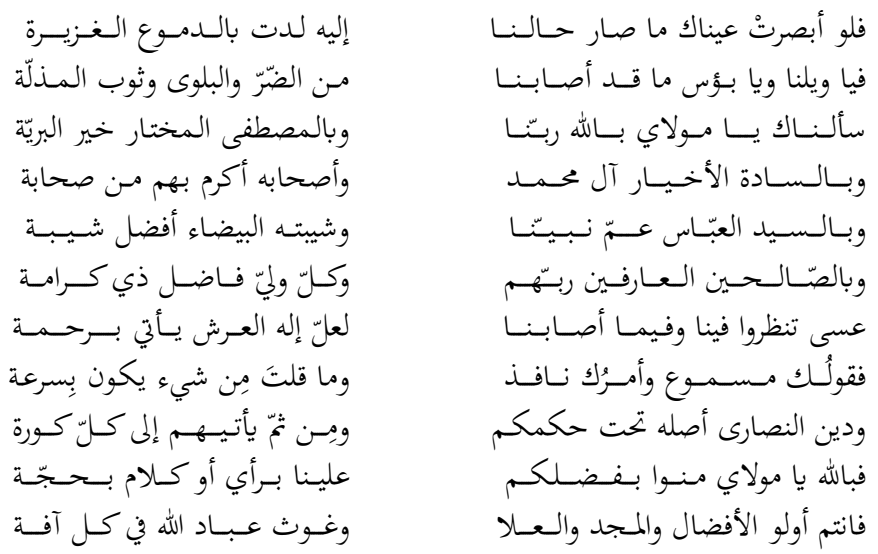

65. Gözlerin bize ne olduğunu bir görseydi, gözyaşlarm dolup taşardr.

66. Vay halimize ve başımıza gelen bu musibet, bela ve zillete.

67. Ey Efendim! Rabbimiz Allah adına ve insanlığın en hayırlısı seçilmiş Peygamberimiz adına sizden yardım istiyoruz.

68. Hz. Muhammed'in soyundan gelen seçkin kimseler ve sahabe adına... O sahabe ne kadar da şereflidir.

69. Peygamberimizin amcası Abbas ve onun beyaz saçı adına ki o ne güzel beyazdır.

70. Allah'ın taniyan salih kimseler ve keramet sahibi faziletli her Allah dostu adına...

71. Umulur ki bize ve başımıza gelenlere bakarsınız ve böylece arşın ilahi bize merhamet eder.

72. Sözünüz dinlenir, emriniz yerine getirilir ve söylediğiniz her şey hemen yerine getirilir.

73. Hiristiyanlarm dininin aslı sizin hükmünüzdedir (hükmettiğiniz topraklardir). Bu sebeple oradan her yere yayilır.

74. Ey efendim Allah aşkına yüceliğinizle bize bir tavsiye bahşedin ya da karşı çıkacak bir söz söyleyin.

75. Sizler yüce, şerefli ve üstünsünüz. Allah'ın ibadet edenleri her türlü afetten kurtarirsiniz.

Buraya kadar olan kısımda bir yandan II. Bayezid'i överken bir yandan da ondan gelecek yüce ve asil bir yardım talep etmektedir. Bu 
74 | R. MEŞE / Endülüs Müslümanlarının II. Bayezid'e Yazdığı İstiğâse (Feryadname) Kasidesi

82. Sizden (hakkımızda olan) mektup onlara ulaştı ancak onlar bu mektubun bir kelimesine bile aldirmadilar.

83. Bu mektup aksine onlarm bize karşı düşmanlıkların ve cüretlerini arttırdı ve kötü muamelede ileriye gittiler.

84. Misır heyeti de onlara ulaştı. Onlara karşı bir kötülük ve bir saygisizlik yapılmadi.

85. Bu heyete biz baskı olmadan küffar dinine razı olduğumuzu söylediler.

86. Kendilerine itaat edenlerden yalancı şahitler getirdiler. Allah'a yemin olsun ki biz bu şahitliği kabul etmeyiz.

87. Hakkımızda yaptıkları açıklamalarda ve sözlerde çok büyük yalanlar söylediler.

88. Fakat ölüm ve yakılma korkusu dinimizi değiştirmeye zorladı ve istemeyerek onların söylediklerini söylemek zorunda kaldık.

89. Hâlâ Allah'ın resulünün dini üzerineyiz ve her an Allah'ı birleriz.

90. Allah'a yemin olsun ne dinimizin değişmesine razı oluruz ne de teslisi hakkında söylediklerini kabul ederiz.

$\mathrm{Bu}$ pasajda şair II. Bayezid'den gelen mektuba değinmiştir. Bu mektup ilk istiğâse kasidesi ulaştığında II. Bayezid'in Rum yöneticilerine Endülüs'teki Müslümanlar hakkında gönderdiği mektuptur. ${ }^{39}$ Ancak bu mektubun onların karşılaştı̆g 1 baskı ve zulmü engellenmediğini aksine onlara karşı olan bu tutumu daha da arttırdığını ifade etmiştir. Ayrıca Mısırda bulundan Memluk Devleti'nden yardım talep etmeleri neticesinde onların da göndermiş olduğu heyetten bahsedilmiştir. ${ }^{40} \mathrm{Bu}$ heyet doğruların söylenmediğini ve yalancı şahitlerle bu heyetin aldatıldığ 1 da ifade edilmiştir. Bunca şeye rağmen onları hala Muhammed'in (s.a.v) dini üzerine olduklarını ve muvahhit olduklarını ikrar etmiştir. Ayrıca dinlerinin değişmesine razı olmayacakları ve teslisi kabul etmeyeceklerini ifade etmiştir.

Daha sonra ise onların kendileri hakkında dinlerini değiştirdiler iddiasına birkaç beyitle dayanak getirmiş ve söyle demiştir:
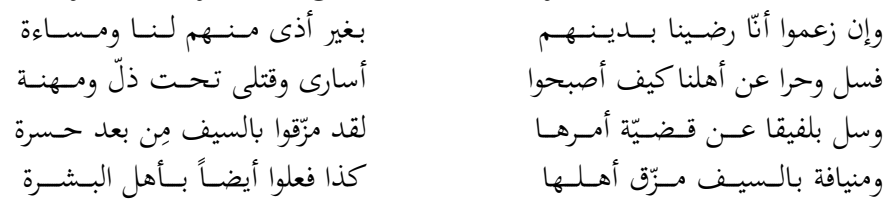

39 Özdemir, Osmanlı Endülüs Müslümanlarına Yardım Etmedi mi?, 286.

40 Bk. Anân, Devletü'l-İslâm fi'l-Endelüs, 5/221. 
R. MEŞE / The Qasīdah (Faryādnāma) Written to Bāyezid II by Andalusian Muslims | 75

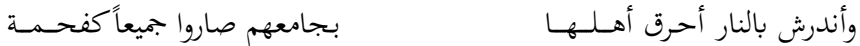

91. Ĕ̆ger onlar bizim herhangi bir baskı ve kötülük olmadan onların dinine razı olduğumuzu iddia ederlerse;

92. Vahr'a, halkının nasıl zillet ve eziyet altında nasıl esir edildiklerini ve öldürüldükleri sor.

93. Belefique'ye, başına geleni bir sor. Büyük bir felaketten sonra kılıçla parça parça edildiler.

94. Munyafe'ye, halkının kılıçla parçalandı̆̆ını sor. Aynı şeyi Buşra halkına da yaptılar.

95. Endereş'in halkın da camilerinde yaktılar ve hepsi kömür gibi oldular.

Burada şair zorla din değiştirmeye boyun eğmediklerini ifade ederken birkaç şehir ve halkının başına gelenleri de ifade ederek aslında bu şehirde yaşayanlar dinlerinin değiştirmediği için başına bunlar geldi. İşte bu şehirlerin halklarının başına gelenler her ne kadar isteyerek dinimizi değiştirdik diye iddia etseler de bizim dinimizi değiştirmediğimiz bir göstergesidir.

Daha sonra yine II. Bayezid'e şikâyetini dile getirerek yardım talebinde bulunarak temennilerini ifade etmektedir:

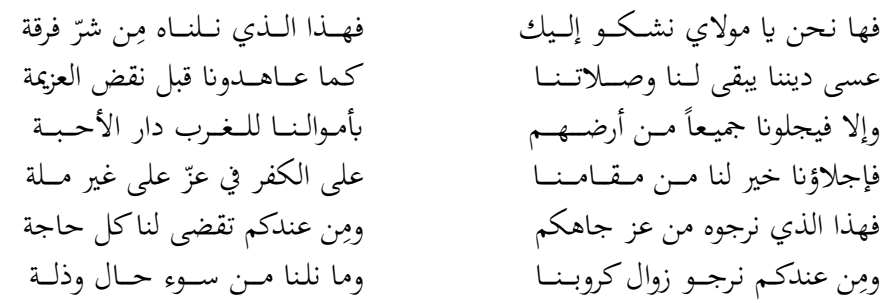

96. İste ey Efendim, biz size şikâyette bulunuyoruz. Bu başımıza gelenler yalnız kalmamızın şerridir.

97. Umulur ki anlaşmayı bozmadan önce bize vadettikleri gibi dinimiz ve namazımız bize kalır.

98. Ya da mallarmuzla birlikte sevdiklerimiz diyarna Kuzey Afrika'ya hepimizi sürsünler.

99. Sürülmemiz küfür üzere başka bir dinde güçlü olarak kalmamızdan daha hayırlıdir.

100. İşte yüce katımıdan dileğimiz budur. Sizin katınıda bütün ihtiyaçlar giderilir.

101. Sizden sıkıntılarımız ve başımıza gelen bu kötü durum ve zilletin giderilmesini temenni ederiz. 
Kasidenin sonlarına doğru gelirken şair yine yardım talebinde bulunarak temennilerini ifade etmektedir. Başlarına gelen bu musibet ve belaları yalnız kalmaya ve kimsenin onlara yardım etmemesine bağlamaktadır. Ardından da dinleri üzerine kalmayı ya da malları ile birlikte oradan sürülmeyi temenni ettikten sonra tekrar yardım talep ederek ya kendilerini bu küfür diyarından kurtarmalarını ya da başlarında bu zilletin bir an önce giderilmesini istemiştir.

Bütün bunlardan sonra son olarak II. Bayezid'e dua ile kasideyi bitirmiştir:
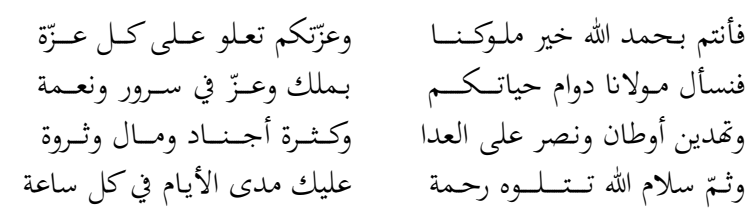

102. Allah'a hamd olsun ki siz meliklerin en hayırlısını. Sizin şerefiniz bütün şereflerin üzerindedir.

103. Rabbimizden sultan olarak, şerefli, mutlu ve nimet içerisinde hayatınızin devam etmesini dileriz.

104. Ülkenize barış, düşmana karşı zafer, büyük ordular, mal ve servet dileriz.

105. Son olarak her daim Allah'in selam ve rahmeti sizinle olsun.

Genel olarak kasideye bakılınca şairin yer yer yardım talebinde bulunduğunu yer yer ise içinde bulundukları durumu tasvir ettiği söylenebilir. Daha önce bahsedilen İbnü'l-Abbâr ve Ebu'l-Beka erRundî'nin istiğâse şiirlerinde kullanılan biçim ve içerik ile bu kasidedeki biçim ve içeriğin biraz farklılık gösterdiği söylenebilir. Söz konusu iki kasidede medih kısımları uzun tutulurken bu kasidede medih kısmı çok uzun tutulmamış bunun yerine daha çok içinde bulunulan durum tasvir edilmeye çalışılmıştır. Aslında bu da Endülüs toplumunun o dönemde ne kadar zor durumda olduğunun bir göstergesidir. Zira şair yaşadığ1 toplumun sıkıntılarını bir an önce dile getirerek medih kısmını zayıf bırakmıştır. Ayrıca baş tarafta selamlama yaparken dahi tasvire kaçması bunun bir diğer göstergesidir.

Selamlama beyitlerinde içinden bulundukları durumu tasvir ettikten sonra şair birkaç beyitle II. Bayezid'e dua etmektedir. Dua beyitlerinde sonra ise Hiristiyanlar ile aralarında olan mücadeleyi anlatmaktadır. Bu mücadeleyi anlatırken yine tasvire kaçmış ve aralarında geçen mücadeleyi ve bahsi geçen anlaşmayı anlatmıştır. Bu anlaşmayı imzalamak zorunda kaldıklarına vurgu yaparak 
Hıristiyanların bu anlaşmaya uymadıklarını ve bu süreçte de herhangi bir yardım görmediklerine değinmiştir. Ayrıca kasidede sık sık yaşadıkları zor durumu anlatmaya çalışan şair yer yer de muhatabına şikâyette bulunmaktadır. Bunun yanında muhatabını övmeyi de ihmal etmemiş ancak bunu fazla uzun tutmamıştır. En nihayetinde de dua ile kasidesine son vermiştir.

Kısaca özetlediğimiz bu kasidenin dili gayet yalın ve sadedir. Ayrıca şair meramını ifade ederken teşbih, mecaz, kinaye gibi anlaşılması muhataba güç gelebilecek edebi sanatları fazla kullanmıştır. Genellikle anlaşılır ve basit ifadeler tercih etmiştir. Bunun sebebi muhatabı edebi sanatlara boğup asıl meramının anlaşılmasından çekinmesi olabilir. Ancak her hâlükârda söz konusu kaside akıcı ve sade olup, maksat en yalın ifadelerle aktarılmaya çalışılmıştır.

\section{Sonuç}

Miladi 711 ile 1492 yılları arasında Endülüs yarımadasında büyüyüp gelişen ve yok olan İslam devletinden geriye kalan kültür mirası bugün bize o dönemin yaşantısı hakkında bilgi vermeye devam etmektedir. Bu bilgi kaynaklarından biri de o dönem yazılmış şiirlerdir.

Endülüs İslam devleti zayıflayıp gerilemeye başlayınca zuhur etmeye başlayan istiğâse şiirlerinin en güzel örneğini İbnü'l-Abbâr ve Ebu'l-Bekâ er-Rundî ile verilmiştir. Bununla birlikte Endülüs'teki son İslam Devleti Benî Ahmer yıkıldıktan sonra orada kalan Müslümanların gördükleri baskı ve zulüm karşısında dönemin güçlü İslam devleti Osmanlıdan yardım talep etmeleri ve bu yardım talebini istiğâse kasidesi ile bildirmeleri neticesinde 105 beyitlik muazzam bir kaside geride bırakılmıştır. Bu kaside Endülüs Müslümanlarının o dönemde yaşadıklarını tüm çıplaklığı ile gözler önüne sermiştir.

Kim tarafından nazmedildiği belirlenemeyen ancak Edebiyat Tarihi kaynaklarında karşımıza çıkan bu kasidede şair, yardım talep ederken Endülüs Müslümanlarının içinde bulundukları durumu tasvir etmiş, yer yer de Hıristiyanlarla olan mücadelelerini ve aralarında imzaladıkları anlaşmayı anlatmıştır. Osmanlı Devleti Padişah'ı II. Bayezid'i kasidenin girişinde selamlamış ve ayrıca da kasidenin muhtelif yerlerinde onu överek dua etmiştir.

Kasidenin büyük bir kısmında şairin tasvir sanatını kullandığ görülür. Sade ve yalın bir dil ile nazmedilen kasidede edebi sanatlara 
78 | R. MEŞE / Endülüs Müslümanlarının II. Bayezid'e Yazdığı İstiğâse (Feryadname) Kasidesi

fazla yer verilmemiştir. Ayrıca şair asıl maksadını basit ve akıcı ifadelerle aktarmaya çalışmıştır.

Son olarak bu hüzün dolu istiğâse kasidesinin her beyti insanı derinden etkilemekte ve bir toplumun baskı ve zulümle nasıl asimile edildiğini gözler önüne sermektedir. Bu açıdan tarihi bir belge olarak tarihin tozlu sayfalarında yerini almıştır. Batı medeniyetinin o dönemde işlemiş olduğu bu insanlık suçu bu kaside ile ortaya konulmuştur. Ayrıca sadece bu kaside değil o dönemde kilise tarafından kurulan engizisyon mahkemelerinin kayıtlarında da bu insanlık suçunun delilleri mevcuttur. Dolayısıyla bu kaside tarihi bir vesika niteliğindedir. Ayrıca söz konusu dönemde yazılan istiğâse şiirlerinin yapısı ve içeriği hakkında da bilgi veren bu kaside Arap şiirinde de önemli bir yer teşkil etmektedir.

\section{Kaynakça}

Abdulbâkî Muhammed, Abdulbâkî Hüseyn. "Sînîyyetü İbni'l-Abbâr dirâse belâğiyye nakdiyye-“. Mecelletü Külliyeti'l-Lügati'l-Arabiyye bi Asyût 30/4 (Aralık 2011), 2293-2341.

Anân, Muhammed Abdullâh. Devletü'l-ìslâm fi'l-Endelüs. 4 Cilt. Kahire: Mektebetü'l-Hanicî, 1997.

Bilgin, Feridun. "Gırnata İşgali Sonrasında Endülüs'teki Müslümanların Asimilasyonu". Mukaddime Dergisi 2 (2010), 53-78.

Ferâhîdî, Halîl b. Ahmed. Kitâbu'l-'ayn. thk. Mehdî el-Mahzûmî İbrâhîm es-Samerrâî. 4 Cilt. Lübnan: Dâru ve Mektebetü'l-Hilâl, ts.

Goran, Selahattin. Endülüs Arap Şiirinde Vatan Özlemi. Ankara: Ankara Üniversitesi, Sosyal Bilimler Enstitüsü, Doktora Tezi, 2003.

İbn Dureyd, Ebû Bekr Muhammed el-Ezdî. Cemheretü'l-lüğa. thk. Remzî Munîr Ba 'lebekkî. Beyrut: Dâru'l-i̇lmi li'l-Melâyîn, 1407/1987.

İbn Mâlik et-Tâî, Ebû Abdillâh Cemâlüddîn Muhammed b. Abdillâh elEndelüsî el-Ceyyânî. el-Elfâzu'l-Muhtelifetü fìl-Meâni'l-Mu'telife. thk. Muhammed Hasan Avâd. Beyrut: Dâru'l-Cîl, 1411/1991.

Îsâ, Fevzî. eş-Şi 'ri'l-Endelüsî fî asri'l-Muvahhidin. İskenderiyye: Dâru'lVefâ, 1428/2007.

Kasapoğlu, Abdurrahman. "Kur'an'da Dini Bir Tecrübe Olarak Allah'tan Yardım Dileme ve O'na Muhtaçlık "İstiâne", "İstiğâse" ve "Fakr İla'llâh". İnönü Üniversitesi İlahiyat Fakültesi Dergisi 5/2 (Güz 2014), 81-127. 
R. MEŞE / The Qasīdah (Faryādnāma) Written to Bāyezid II by Andalusian Muslims | 79

Makkarî, Şihâbuddîn Ahmed b. Muhammed el-Tilimsânî. Ezhâru'r-riyâd fi ehbâri el-Kâdî '̇yâd. thk. Mustafa es-Sekkâ vd.. 3 Cilt. Kahire: Matba'âtu Lecneti't-Te'lîf, 1358/1939.

Merrâküşî, Ebû 'Abdullah Muhammed b. 'Abdulmelik el-Ensârî. ezZeyl ve't-tekmile lî kitâbi'l-mevsûl ve's-sila. thk. İhsân 'Abbâs vd.. 4 Cilt. Tunus: Dâru'1-Ğarbi'l-İslâmî, 1433/2012.

Mekkî, Tahir Ahmed. Dirâsât Endelüsiyye fîll-edeb ve't-târîh ve'l-felsefe. Kahire: Dârü Maârif, 1407/1987.

Sâmerrâî, Halîl İbrâhîm vd.. Târîhü'l-Arab ve Hadaratuhum fíl-Endelüs. Beyrut: Dâru'l-Kitâbi'l-Cedîdi'l-Muttehide, 1421/2000.

Şeyban, Lütfi. "Hıristiyan İşgalinde Endülüs Şehirleri”. Eski Yeni: 3 Aylık Düşünce Dergisi 1 (Bahar 2006), 29.

Özdemir, Mehmet. "Gırnata”. Türkiye Diyanet Vakfı İslam Ansiklopedisi. 14/51-57. İstanbul: TDV Yayınları, 1996.

Özdemir, Mehmet. "Endülüs". Türkiye Diyanet Vakfı İslam Ansiklopedisi. 11/211-225. İstanbul: TDV Yayınları, 1995.

Özdemir, Mehmet. "Morisko". Türkiye Diyanet Vakfı İslam Ansiklopedisi. 30/288-291. İstanbul: TDV Yayınları, 2005.

Özdemir, Mehmet. "Müdeccenler". Türkiye Diyanet Vakfı İslam Ansiklopedisi. 31/465-467. İstanbul: TDV Yayınları, 2006.

Özdemir, Mehmet. "Osmanlı Endülüs Müslümanlarına Yardım Etmedi mi?". İslâmî Araştırmalar Dergisi 12/3-4 (1999), 283-296.

Uzunçarşılı, İsmail Hakkı. Osmanlı Tarihi. 2 Cilt. Ankara: Türk Dil Kurumu Basımevi, 1988.

Yiğit, İsmail. "Nasriler". Türkiye Diyanet Vakfı İslam Ansiklopedisi. 32/420424. İstanbul: TDV Yayınları, 2006.

Yüksel, Azmi. “Endülüs'ten II. Bayezid'a Anonim Bir Şiir". Belleten 3/205 (Aralık 1988), 1576-1583.

Zebîdî, Muhammed b. 'Abdurrezzâk el-Hüseynî Ebü'l-Feyd. "Tâcu'larûs min cevâhiri'l-kâmûs. thk. 'Alî Hilâlî. 5 Cilt. Kuveyt: Matba'âtü Hukûmeti'l-Kuveyt, 1423/2003. 